\title{
Globalizing the Trade Policy
}

\author{
Iqbal M. Khan \\ Senior Fellow Entrepreneurship, Lahore School of Economics \\ Email: ibajauri@gmail.com
}

\begin{abstract}
Globalization has been the most captivating and engulfing subject of the decade of 1990s. The impact of this subject has been such that it has brought about the new economic era. Even the breakup of the Former Soviet Union is considered the casualty of globalization. The competitive advantage of nations have led to the emergence of forces of globalization and WTO is the ultimate outcome of the era and globalization. Brettenwood philosophy and dictates do not rule the world, the new economic order that rules is the World Trade Organization and the dictates of Trade Policy that has emerged as ultimate outcome carrying a clout never perceived before. The global economy is now shaped by Trade Policy, which is the new leverage for political and economic policy direction. We are infact in need of a new rudder to steer the course of trade as the world has turned into a Boarderless World. For the first time the concept of Tailored Trade Policy have been understood and the value of tailoring the policy to suit and serve the cause of a nation. It has therefore become important to manage such a policy efficiently and suited to the interest of nation.

It is in this context the paper evaluates the evidence and evolves the reasoning to develop a market minded, trade policy. The question that the paper answers is "Is it necessary for us to understand trade policy of other countries? And does trade policy matter? The paper eventually answers and proves the Hypothesis to be correct and subscribes to the requirement of the Hypothesis of radical change. It believes in the maxim that "only the living nations live out the experience of change no matter how bold the change".

The literature review covered a wide range of topics that are current to globalization, competitive advantage of nations, market orientation, national trade strategies, various theories of trade, all inclusive trade, and the current environment of discontinuity.

There was also a survey of selected countries to examine their policies and see the causes of their success or failure. This survey of trade policies of actively trading nations and their track record in view of macroeconomics and microeconomics policies is new ground breaking information in developing strategic policies. It also emphasizes the need to go radically and adopt a new kind of Ministry of Commerce - a market minded Ministry, and to select strategic industries to make them competitive. And above all to focus on developing Human Capital to man the Ministry.

The paper then goes on to recommend under the highly competitive environment, the need to adopt a policy of Trade Ambassador, Trade Academy and a Trade Bank. The final analysis of the paper is to have a globalized trade policy that is sensitive to development in the global environment, a policy that is sensitive to its trading partners and their trade policies and developing highly competent and highly knowledgeable ambassadors or territory commanders to bring the economic benefits to the nation through trade.
\end{abstract}

\section{A. INTRODUCTION}

\section{Introduction}

The decade of 1990s has seen a tremendous growth of literature on the subject of Globalization. The impact of this subject has been such that it has brought about the new economic era, something which the west has been hoping would come about. Almost everything was related to this subject and the breakup of the Soviet Union is also considered a casualty of globalization.

But one of the most significant feature of this decade has been the emergence of the WTO, which has subsumed the GATT. A new meaning has been given to the word 'competitive'. The competitive advantage of nations are measured and have become benchmark for growth and respect and recognition. It is no longer the dictates of "Brettenwood" that rule the economic order. There is in fact a new economic order. There has been a paradigm shift from 'Free Trade' to 'Managed Trade' and the Developed World favors the managed trade. Trade was once considered a consequence of economic development, and hence received secondary importance but today it seems to be growing into significance. It now has a clout which it never had before. It has come of age and is now the new leverage for political and international policy direction to adopt for supremacy of the world order and shaping the Global Economy.

Influential public policy writers such as Kenichi Ohmae have propounded the concept of borderless economy. He has also advocated a change in the Paradigm of the policy towards trade. He say in his book "The End of the Nation State: The Rise of the Regional Economics" that

"It is my strong belief that, so long as the old principles continue to shape policy, the century-

long gap between intention and result cannot be closed by better execution or implementation.

Nothing can close it. The Principles themselves have to change".

This is precisely what this paper plans to examine: To look into a change in the concept of trade policy for the 
future. The future is a rapidly changing and 'discontinuing' era (Drucker). The quality of life may move a little faster in some nations but the transition into the new world economic order may yet be the stumbling block if the nations do not consider revising the policy principles and adopt the "global logic" unleashed by the forces of the environment and globalization, they will still be unable to bridge the gap of centuries between the developed and the developing world (Ohmae).

"Indeed, as the $21^{\text {st }}$ century approaches and as what I call the four 'I's - industry, Investment, Individuals and information - flow relatively unimpeded across national borders, the building blocks concept as appropriate to a $19^{\text {th }}$ century, closed - country model of the world no longer hold". (Ohmae 1995, pg viii)

The trends were different in this decade. It was a period of change in the trends towards product strategy, a trend of change towards product transformation; change in trend for a high fiber food product: change in trend for just not tea but tea extracts from tea leaves or from fruits ${ }^{1}$. The trend has been towards concentration of farm integration and growth of the average size of the farm. Trend has been to focus on bio-technology and redefining the process. The trend was and is information technology, ecology- green markets, environment concerns and also towards changing governments' role; it was also a trend towards international linkages. The trend we saw is 'Sovereign Credit Rating' and this was the most revolutionary ${ }^{2}$. All these trends were universally felt. It was in fact a global trend. It proved one very important lesson, "Do the Obvious, do it well and do it quickly". Because globalization would effect all the countries and no one was immune to it. The customer was more knowledgeable and more demanding. The investors know the trend and demanded what was trendy. We also saw that sovereign credit rating were the first constraint on sovereign ceiling.

Kenichi Ohmae "End of the Nation State"

1. For example there has been a growth in demand for concentrated green tea extract for cardiovascular system.

2. Sovereign credit rankings were used by investors as guides to the likelihood that national government will pay their debts.

So what are the choices? Do we fight globalization, can it be changed? This, as we can see, is beyond our capacity as a nation or even a group of nations. We have but one choice - accept globalization and move rapidly. Build on competitive advantage - and this comes with policy and recognizing that a certain discipline would be required and to bring in the change through policy that recognizes the reality of today. Perhaps like Michel Porter says Macro-economic factors are not sufficient. The change has to come at the firm and industry level and the policy must provide sustainability and productivity. Public and private sector must work together to bring about Macro-economic growth. We also come to recognize that knowledge is replacing capital. What we really need is a policy that has "Management of Knowledge" as the central theme of the policy. There has to be an acute awareness of competitiveness. It would require to have proliferation of seminars and workshops on competitiveness, and modalities to follow up the out come of these seminars and conferences. What we need to understand is that we must adopt a cross disciplinary approach to design the future Trade Policy. This means that all sectors of the economy communicate with the other and such a concept in designing a trade policy would be the Total Trade Policy that would provide competitive management.

\section{Hypothesis of this Paper}

Hence our Hypothesis would be that, in the modern context and environment, we must introduce a New Trade Policy perspective that takes into account globalization in the entire context of Trade Policy and develop a Tailored Trade Policy. To pursue national economic goals through competitiveness, superior to our competitors:

$\mathbf{H}_{1} \quad$ If we do not change the concept and the old principal of Trade Policy for economic prosperity, the gap between policy and implementation cannot be closed by better execution.

It was in this period the world realized that trade has positive impact on growth; we began seriously monitoring the trade to GDP ratio. As seen in the final decade of the $20^{\text {th }}$ century, trade is the high ground of economic development and economic policy.

$\mathbf{H}_{2}$ If the nations do not consider revising the policy principles, adopt drastic change to combat forces of environment and globalization, they will be unable to bridge the gap of centuries between the developed and the developing world.

$\mathbf{H}_{3} \quad$ A policy that does not have as its central theme, the Management of Knowledge, will not hold its ground of development.

Therefore, our hypothesis, that in order to compete in the new economic order, Trade Policy has to be seriously considered, thought-out, and re-designed. It should be a process of "creative destruction" as prescribed by Schumpeter, the famous Austrian Economist. Without a revolutionary concept and without recognizing the realities of today no strategy would succeed through patch work approach. It should not be left in the hands of mere bureaucrats; and announced as a routine affair. It is the job of specialist that cut across the board.

$\mathbf{H}_{4} \quad$ That a revolutionary concept of Trade Policy recognizes that Globalization would effect all countries and no one is immune to it, hence it must work towards creative destruction approach.

$\mathbf{H}_{5} \quad$ That the concept of trade policy has been so much influenced that it is pragmatic to globalize the Trade Policy itself. The harmonizing of trade policy is the norm. 
The paper will take into consideration all these factors while suggesting a design for a trade policy and will hence examine literature to look for the impacts of these factors on our trade and economy and also study successful examples of policies and how they have become globalized. If all these factors are taken into consideration, we can call this Total Trade Policy Management and globalizing Trade Policy.

\section{B. THE ENVIRONMENT}

\section{Understanding WTO, the Successor of GATT}

Since this decade of 1990 had been dominated by events leading to WTO, we must understand the phenomenon. The 3 guiding principles embodied in the articles of GATT were:

Reciprocity

Non-discrimination

Transparency.

Within the past 30 years of this decade, there has been a proliferation of new sorts of trade protections the "hardcore" non-tariff measures. These non-tariff measures are more difficult to monitor and fight against, and there are no reliable estimates of their impact on world trade.

By 1990 many developed countries agreed and favored "managed trade" as the only way to meet the economic challenges of the next decade. At the same time the countries of Eastern Europe were fleeing Comecon-managed trade in a fully worked out form - and asking to join the largely open international trading system that the GATT had built. The developing countries present the same problem. As the industrial countries enthusiasm for liberal trade cooled in 1980s, many of the worlds poor countries began to see the advantages of liberal trade and this lead to the collision path. (Economist: Sep. 22, 1990)

To be able to succeed, the industrial world has realized that they must control trade by means of an economic organization powerful enough to control their interest in the third world countries. It is being perceived that WTO is at least the first embodiment of this thinking*. In the WTO first Conference Dec. 1996 in Singapore, it was also agreed to recognize the right of labor associated with trade.

The $2^{\text {nd }}$ WTO Conferences was an eye opener, and the WTO was in for an onslaught from the developing world. At Seattle thousands of protesters marched against globalization. How long is this sustainable is yet to be seen. But a new awakening is visible and the pressure on the industrialized world has come to bear on from a totally new source, the NGOs and the e-mail campaign demanding the recognition of the third world problems. This was the result of the Technological revolution (ITC) that has come about unfettered and unleashed. It is a double edged sword and it was accessible. The knowledge economy has been accessed by an unexpected quarter and it sounded the first warning shots. At Doha it was a declaration to make trade work for all, whereas in Cancum it was a backlash to register the disappointment of developing countries and the voice become the call of the developing world.

\section{The Macroeconomics and Competitiveness Environment}

We have argued above that macro-economic environment is central to the international competitiveness requirement. We have sufficient evidence to believe that it has impact on the economy to grow, upon the health of the tradable sector, upon the balance of payments. The policy thus takes its initiative to bring about economic stability and to prevent a conflict that would prevent growth. What matters is to understand that though the economy may be stable but the policy may not be conducive to growth (Haque 1995). He goes on to explain this fact in his $3^{\text {rd }}$ Chapter of "The Macroeconomic Environment and Competitiveness"

"The predominant view is that unless an economy has been stabilized, effects to stimulate growth are futile (see, for example, Corden 1990). It is argued that policy reforms must first be aimed at achieving economic stability; only later should long-term problems of growth and competitiveness be tackled. A complementary view holds that in getting the fundamentals right - that is, reducing budget and trade deficits to manageable levels, maintaining competitive exchange rates, and eliminating distortions in the financial sector - an economy will have made the necessary adjustments and no specific growth enhancing policies will be needed. This argument also holds that it is not usually possible to target specific discretionary policies at the determinants of economic growth."

*An informal agenda is already in place and we saw the effect of this on IRAN, IRAQ, LIBYA, CHINA, and ALGERIA. We also saw the various new factors of this agenda in the shape of child labor, human rights violations, environment unfriendly packaging, dyes, pigments, materials, and intellectual property rights.

He has argued that there is evidence to establish that economic stability and macro-economic policies have to be considered in full conjunction to bring out economic growth. Policy will therefore, be the most important rudder to guide us through the sea of change that this era is experiencing. Another complementary view that he holds is that investment is an important factor also. He quotes a statement by the MIT Commission on Industrial Productivity.

"Investment, in its broadest sense, is crucial for productivity, and the macro-economic environment largely determines the level of investment” (Dertouzos, Lester, and Solow 1989, 
p.35)

Hence productivity will play an important role in economic growth and will therefore develop the economy to be competitive in order to boost the 'tradable' sector of the economy. While emphasizing productive efficiency and competitiveness he says:

"Because catching up with the industrial economics is a major goal of developing countries, it is the rate of improvement in productive efficiency over time that must be of primary concern" (Haque 1995).

And the most powerful and meaningful definition of Productivity is from (Salter, 1996. p.I) who has done pioneering research work on this sector.

"The difficulty is ... that the interpretation of even the simplest measures of productivity raises a host of very complex problems. For behind productivity lie all the dynamic forces of economic life: technical progress, accumulation, enterprise and the institutional pattern of society" (Salter 1996. p.1)

\section{THE LITERATURE REVIEW}

1. "Plowing the Sea" Fairbanks and Lindsay:

Michel Fairbanks is the author of "Plowing the Sea" and has been an ardent supporter of Michel Porters theory of "Competitive Advantage of Nation". He has adopted a stance in favor of developing countries in this book. $\mathrm{He}$ has said that microeconomic, as a development tool is as important as macroeconomic. As a matter of fact microeconomic is rooted in the nature of firm strategy, in the institutions that support trade, the allocation of resources and the development of policies to promote trade and develop environment to make a conducive environment for trade. Fairbanks and Lindsay have worked in many developing countries hence they based their recommendations on their experience. They have taken this stance that developing countries must adopt a new economic paradigm. This paradigm shift should be based on the development that is taking place in the world today. Patch work; and corrective measures in policy will not work, what is required is the revolutionary approach which we have called Total Trade Policy Management.

The authors of "Plowing the Sea" further go on to say that it is essential to understand the distinction between comparative advantage and competitive advantage to participate in the global economy today. This calls for understanding the strength and weaknesses of competing firms and their competitors, study the needs of the markets, learn to create value to their products and services and to vehemently strive to earn returns. This means that firms in developing countries must capture greater value in market place not merely improving quality but by choosing where to compete and by adding service dimensions to their products. It also calls for innovating new product characteristics through a process of "creative destruction".

They have defined competitiveness as sustained growth in productivity resulting in rapid growth in income and purchasing power for the average citizen. They have reiterated the basic and fundamental economic reality of developmental growth that low cost, low labor expenditure industries will not enhance the general income level of a country. Investment in human capital must correspond with the nations microeconomic circumstances and must be focused towards the highly productive and efficient industrial sectors that will form the future thrust industry of trade for the country.

This book (Plowing the Sea) is based upon the work of Michel Porter, James Austin and Chris Argyris but shows how the competitiveness ideas can be applied in practice. The book lays the foundation to design a trade policy for the current age of discontinuity and fierce competition. Without evolving a tailored trade policy to suit a countries natural endowment and consistently up grading the sophistication of company strategies and the quality of national business environmental, it is not possible to participate in this age of globalization. The developing nations have a tumultuous task of competing in this age and policy must support the development of a total environment.

"Equally, if not more, challenging is getting change to happen, because of disagreements over
the appropriate competitiveness paradigm, deep seated suspicions between business and
government, over lapping and conflicting roles and responsibilities in government itself and
other causes". (Michel Porter 1997)
$\mathbf{2}$ "The Age of Discontinuity" Peter Drucker

\section{2. "The Age of Discontinuity" Peter Drucker}

Globalization of the world economy is inventible and is here to stay. If the concept of competitiveness is understood and all key players from Government to firms work together to be innovative (in fact be greedy to innovate as Peter Drucker says), we will be able to exploit the opportunities.

This communication and information technology works in many ways. Information is an essential input in economic activities. Globalization process will accelerate as the information revolution accelerates. Private sector companies will find newer gain. This is a period of Networking the World; the internet era and the cyber universe is expending at an explosives rate. Internet has made inroads into commerce. Traditional trade has been re-defined. And internet by nature is borderless and ecommerce also cuts across borders. All these have opened 
new opportunities for trade. Peter Drucker says that knowledge is replacing capital and management of knowledge would be the central theme of economic policies. In fact all national goals would focus on the management of knowledge and mastering this phenomenon would give clout to the country that can position Knowledge Management into the Trade Policy. This in itself would combine policies and business to make economic scenario. This essence of such a trade policy would be educating and developing human resources to the highest level of competence.

3. "The End of the Nation State" and "The Borderless World" Kenichi Ohmae's

Coming to another very important perspective of the globalization we need to examine Kenichi Ohmae's "The End of the Nation State" and "The Borderless World". It is one of the most influential thinking that contradicts the work of Michel Porter. Here again we come across a treatise to a trade concept. First he defines that globalization cuts across borders and eventually borders will become meaningless. He has applied this to the Triad which he calls the Interlinked Economy or ILE, which consist of Europe, Japan and the United States, and which is home to the richest fifth or the worlds population. Translated into figures it is a population of about a billion people who produce and consume nearly four-fifth of global output of goods and services. According to him within ILE the significance of national boundaries have diminished and over powered by ever increasing flows of international trade and investment. According to him this augers well for world trade. Such a situation is achieved only by doing away with obsolete policies and by bringing in new policy initiatives revolutionizing the Trade Policy Concept. The reason he cites is that the optimal location of production, would be outside the (Triad) ILE. It would lower the cost, increases output which would lead to raise in the standard of living. He has also emphasized that high technology industry should be adopted such as the microchips production or go for knowledge economy. Such an integrated economy as the ILE would be the engine of growth in their region and attract the satellite countries below $\$ 10,000$ per capita income to follow the ILE engine and abandon the protections in policy and at the same time open doors to imports and foreign investment.

The criticism to his concept was that by 1992 when European Community integrates it would raise the walls of protections in barriers to the disadvantage of the two other axes of the triad. However, globalization has been rapid and all engulfing which has resulted in repositioning of policies by all the developed countries. These policies have universally fallen in line with the agenda of the WTO and are now growing in strength after assessing their Economic and Trade Health.

He has also been ruthless in his criticism of the Japanese, both pointing out that:

"Japan is a bureaucratic country and not a political one. The Diet (Parliament) plays a minor role compared to the powerful bureaucratic system".

$\mathrm{He}$ is also critical of its stance based on its culture and single values system. Since globalization is the dominant feature of the environment the Japanese will have to adopt and be a global player. It will have to evolve policies to usher in a new trend of policy towards trade in an age of globalization.

The lesson to be learnt from this book is that the conflict between the interest of the governments and those of evolving market places will ultimately be resolved by breaking up of boundaries of trade and by the drastic reduction of state power. The time has come to recognize that policymakers must be prepared to adapt to the primary forces shaping the global economy. Though he says that:

"The information led transition to a genuinely borderless economy would not call into question the relevance of nation states as meaningless units of economic activity”...

On the maps that mattered, there were and always would be borders between countries. The precise line of demarcations might shift with events, but the fact that such lines existed would not. In his book "The End of the Nation State" (1995) he strongly argues to opt for a radical approach to the Trade Policy when he says:

"The beginnings of a new set of principles for thinking about why some regions prosper economically and others do not, and why traditional policies based on traditional principles simply cannot provide an adequate guide to the borderless world. It is my strong belief that, so long as the old principles continue to shape policy, the century-long gap between intention and result cannot be closed by better execution or implementation. Nothing can close it. The principles themselves have to change".

4. "Interpreting National Strategies" James Austin

In the book "Managing in Developing Countries", Austin has explained how to interpret the National Strategy. He suggests that the national environment should be understood, because economic, political, cultural and demographic factors shape the government's strategy. National goals and strategies set the focus for development. "National strategies are expressed in terms of a set of public policies" and as we can see that to implement policies we need instruments and institutions. These subsequently impact the industry and the firms. The final step in the "Public Policy Impact Chain" is the interactive feedback mechanism, which can influence the form and substance of the policy, the strategy and the implementation process. But he also cautions that in Developing Countries it is more complicated because of the rapidity with which the policies change.

Central to all strategies is the development of an industrial base and the two main approaches to industrialization 
are Import Substitution Industrialization (ISI) and Export Promotion Industrialization (EPI). Out of the two the EPI has a very successful track record. It "focuses on the export market through international competitiveness. It aims to use the stimulus of large external markets and the discipline of world competition to create an efficient industrial base".

Understanding this phenomena helps in devising policies that emanate from strategy. It helps us also to understand that it is essential that the ultimate goals of the two (policy and strategy) has to be the same. It provides us a conceptual map to interpret strategies implication in government policies. It also enhance the understanding of how to conceive a trade policy and the implication of other sectors of the economy.

\section{5. "What is a Competitive Nation"? Michel Porter}

According to Michel Porter, what really makes a Nation Competitive is how its firms compete at home. These firms raise the nation's standards of living through high levels of productivity. No country in the world has every firm or industry competitive. In this book "Competitive Advantages of Nations" he says:

"Is a competitive nation one whose exchange rate makes its goods price competitive in international markets? Both Germany and Japan have enjoyed remarkable gains in their standards of living - and experienced sustained periods of strong currency and rising prices. Is a "competitive" nation one with a large positive balance of trade? Switzerland has roughly balanced trade; Italy has a chronic trade deficit—both nations enjoy strongly rising national income. Is a "competitive" nation one with low labor costs? India and Mexico both have low wages and low labor costs-but neither seems an attractive industrial model".

"Japan, Italy and South Korea have all enjoyed rapidly rising living standards despite budget deficits, Germany and Switzerland despite appreciating currencies, and Italy and Korea despite high interest rates".

He cites examples of high wage countries such as Germany, Switzerland and Sweden who have prospered despite these beliefs. He says:

"How then, can one explain the success of Germany, Japan, Switzerland, Italy and South Korea-countries with limited natural resources?"

And he also says that subsidies "have propelled Japanese and South Korean auto, steel, ship building and semi conductor Industries into global preeminence".

The experience from these examples is that microeconomic factors shape success factors of a competitive nation and these factors are what shape the core competences and develop a competitive nations.

6. How Developing Countries Trade: (What Led to the Significance of Trade Policy)

Sheila Page says: The Milestone year in the history of Trade was the year 1974. It marked the turning point in Trade Policy. It also marked a point which saw huge growth of trade, its composition which included manufactures from developing countries besides commodities. It also saw the emergence and the importance of different trading groups. It dramatically changed the war-induced changes and development optimism and enthusiasm of the 1960s. The GATT negotiations step-by-step had removed the barriers to trade, tariff were lowered and regional trading blocs came into existence that developed trade patterns within regions that led to the economic development through trade. It ended the era of commodity price boom. This turning point had also seen the phase in trade industry when Generalized System of Preferences was introduced. The economic of most industrial countries were expanding and so was the growth of the Newly Industrialized Countries (NIC) expanding faster then any time in the history of economic development. The significant change in the Newly Industrialized Countries was the growing share of exports in the GDP and the total output. It also saw that manufactures becoming the significant export of these countries. The primary focus was on replacing the imports and promoting the production of manufactures for export. (Page. 1994)

The era had ushered in the growth of products and production of a host of products at low prices and at a fairly good level of quality. To push the products into the export markets had become important. The concepts that were prevalent were the "advanced strategic economic theories". It was also noticed that lobbying had become the norm in promoting exports. The new Intervention in trade at this moment in time was Foreign Direct Investment (FDI). Other traditional intervention in trade acquired new importance "There was a growing share of aid-financed trade for the poor countries in 1980". Similarly Multinational Cooperation (MNC) became significant players as they began looking for supply sources and strategic alliances to produce their products. But they were highly sensitive to the investment climate of the host country. They were interested in the Trade Policies and now were able to compare the policies of given number of countries. It can be seen that MNC can exploit more efficiently, the same opportunities which are being utilized by smaller local firms. This brought in another wave of another kind of industrialization. This thus is arguably another ground for a policy induced trade. This brings us to the question that such development; can it be induced by an appropriate trade policy - a policy that would take into consideration the total factors and the management of trade?

The review of literature, through not exhaustive, helps us to arrive at an awareness that trade today is multidimensional and it also helps to draw conclusion from the experiences and the development that is taking place in the world today. In trying to develop a thought process that gives an approach in designing a trade 
policy but one that is suitable to a developing country by keeping in consideration all the developmental and growth factors. Also keeping in consideration the implementation aspect and trying to see what will be the most suitable approach in selecting the vital features of a trade policy that can be most efficiently applied to the trade of a developing country (Page. 1994).

However, it appears at the out set the changes taken together have created an international system which is more subject then in the past to policy intervention. (Page 1994)

\section{Is it Necessarily for us to Understand Trade Policy of other Countries? Does Trade Policy Matter"}

Generally the concept of trade that prevails with nations is that international trade is policy driven. Within this frame of reference what matters is the economic efficiency of that state. More often then not most countries have lacked confidence in their own trade policies. Sheila Page in her book "How Developing Countries Trade" has examined seven developing nations across. Africa, Asia, Latin America the Caribbean and South Asia. She observes that the trend in the 1960s and 1970s was that each country's own trade policy only considered its concerns and ignored its trading partners market, its strength and its weakness. These problems were considered secondary, and 'disdainfully treating developing countries as deserving of their failures'. The change in trend came about in the 1970s. The response was political in seeking to improve the status of their trading partner. It was in 1974 that UNCTAD spelled out a case of responsibility on Developing Nation to go for import Promotion Programs as part of trade policies to upgrade the trading practices of their trading partners in the Developing Countries. As stated above this higher concern with Trade Policy of the industrial countries date from 1974. It also ushered in the phenomenon of active lobbying by developing countries to obtain a footing in the trade policy of the industrial countries, and for preserving preferences in their favor. However, by 1994 the Uruguay Round progressed in its thinking towards a more regulated and more liberal international trade regime as mentioned above in the introduction.

This development led to the emphasis on Trade Policy for Developing Countries though most still lacked this confidence in their governments to come up with effective Trade Policies. Therefore, it became all the more necessary to study the Trade Policies of other countries and to understand their markets. "There is interaction directly between the trade policies of a country and those of its trading partners, and between different perceptions of these" Sheila Page.

The conclusion that emerges from the review of the literature so far and from the development that has taken place in the trade scenario and emergence of the WTO is that, policies do matter to trade. In fact Trade Policies have revolutionized the concept of trade while approaching the New Millieum. What also matters is the way in which they affect trade and through trade the economy and the society. As seen from the conclusion drawn above from Michel Porter, Peter Drucker, and Kenechi Ohmae that it depends strongly on how exporter respond to them, and not on the legalities of the trade polices. Hence the microeconomic aspect is going to be the dominating influence for competitive advantage which the trade policy would aim as its Mission.

"That the ways in which (trade) Policies work through beyond exports to the rest of the economy, and how changes within the economy interact with the policies and affect exports, depends on a variety of conditions of each country ... the importance of competition and the role of intervention".

In making this statement, Page has validated the concepts of Peter Drucker and Michel Porter".

\section{POLICY REVIEW OF ACTIVELY TRADE COUNTRIES}

\section{Trade Policy of Actively Trading Nations: Experience}

In order to understand the importance of Trade Policy for developing countries some policies are being reviewed. The countries selected are Japan, Taiwan, Singapore, Malaysia, South Korea and Hong Kong.

\section{1. i Japan}

"A Strategy for Economic Growth" Government of Japan

In the postwar era in Japan, the power to sanction the import of goods as well as the import of foreign technologies came to be concentrated in the Ministry of International Trade and Industry (MITI). MITI also made itself Japan's decision center on what industrial policy to follow, on what industries to build up export that would become vital for Japan (with the end of US aid and off-shore procurement). It also had its influence on Japan's banks. The banks looked to MITI for leads on what investments to make, knowing that the suggested investments would enjoy state protection and support and indicate decision for economic growth. The Japanese were however, conscious of too much concentration of powers. They consciously prevented that by checks and balances.

The Japanese looked ahead after independence to revitalizing their economy and concluded that policies would have to be framed with one key consideration: what impact they would have on the balance of payments. The Ministry of Finance put this point as follows in its General Survey of the Japanese Economy, which appeared in 1945.

"The position of Japan in the world economy has been completely changed by the defeat, and 
Japan is becoming even more dependent upon the international economy than she was before the war. The future of Japan's economy, therefore, depends largely upon the course of balance of payments.

Given the overriding importance attached to the payments picture, Japan would clearly need to develop exports. As a corollary, she would need an industrial policy to select potential export industries, to channel investment capital their way and to make export industries competitive with their international rivals.

The main role of MITI is to arrive at a vision that may serve as a policy target and to persuade and guide industry towards that vision. Furthermore, in creating this vision, MITI seeks the opinion of business, consumers, and men of learning and experience".

In simple terms this was the propounding of the concept of 'export oriented industrialization' which stood in contrast to the mood of the day when the World Bank group was propagating the "Import substitution industrialization".

\section{1. ii Basic Philosophy and Objectives of Japanese Policy}

The Ministry of International Trade and Industry decided to establish in Japan industries, which require intensive employment of capital and technology. Ordinarily, encouragement of such industries would seem to conflict with economic rationalism. But, from a long-range point of view, these were precisely the industries where income elasticity of demand proved high, technological progress rapid, and labor productivity, fast.

It was a combination of good luck and wisdom spawned by necessity, Japan has been able to concentrate its scant capital in strategic industries. What lesson can be learned from this? To adopt a competitive advantageous policy a nation has to go into an industrialization policy of high tech industry \& IT industry, robotics and multimedia, gems \& jewelleries to cite a few examples.

Based on its policy of selective controls through trade, Japan was able to give direction to its growth that focused on improving balance of payment and thereby it has grown into an economic giant.

\section{1. iii The South East Asian Economies}

The rapid industrialization of Singapore, Taiwan, South Korea and Hong Kong after 1960 was an economic phenomenon unparalleled in human history. They began by focusing on labor-intensive industries and following an export-promotion strategy, they surged ahead in economic progress. In 20 years they rose from the ranks of the less-developed countries (LDCs) to challenge the industrial world for export markets. Their unparallel real growth rate of more than 9\% per year in the period 1965-84 was one of the highest in the world. This remarkable performance was achieved despite major international disturbances, such as the two oil price shocks of the 1970 s. This period also saw the recessions in many industrialized countries. The achievement is more commendable despite the fact that these states lacked the natural and human resources usually necessary for rapid development. Today Singapore has turned into one of the richest and modern city states in the world. Malaysia and Singapore are South-East Asia's economic super stars and enjoy the highest living standards in the region (Economist Feb 2000). The GDP per head in Singapore is $\$ 25,500$ and in spite of the Asian crisis the Malaysian economy rebounded by 1999, which came about when Malaysia refused IMF help and did not toe the IMF line. But the secrets of the success and rapid economic growth were its strong regulatory environment for financial institutions and the selective controls on the money market. (Economist Feb 2000)

The East Asian countries having confronted the trauma of one of the worst economic-currency-crisis. They have consequently decided to work together harder and to cooperate with China, South Korea \& Japan thus forming an informal yen zone. This fact will enable this regional bloc to carry enough clout to rival America \& European Union. It is quite clear that 1999 was the recovery year with economic growth of various level for East Asia economies including Japan.

But the historical perspective of some of these states will make the picture clearer for us to understand the need to have a Total Policy Management Perspective.

\section{Pakistan and the Trade Policy Dimension}

On the other hand Pakistan represents a scenario of apathy towards trade policy. Taken as a whole, both the public and private sector are dissatisfied with the aspect of consultation. The European Commission funded a study under Trade Related Technical Assistance for the Government of Pakistan. ITC implemented with its exports, this study in 2007. The funding was as follows.

The process of preparing the Trade Policy by the Government officials was not willing to respond to any feedback from private sector. No business input was accommodated in forming the free trade agreements leading to misalignment of commitments with commercial priorities. This "lack of accountability in trade policy decision making prompts questions for trading partners about the durability of Pakistan's trade policies compliance". It was found that both the public and private sector blamed each other for the defective trade policy and its historical pattern. It was observed that "short comings in the current depth, interactivity and timeliness of the dialogue on trade policy are the responsibility of both sides". There is a lack of shared "language" for describing the trade policy objective. 
Private sector representative are willing and even keen to improve the dialogue with government on trade policy matters but no decision has been taken at a political level that requires the bureaucracy to respond to this private sector demand. The officials to whom we spoke are at best skeptical that anything of value would emerge from changes to the current consultations procedures and are not apparently under any pressure from Ministers or from the Parliament to make any change.

Efforts to initiate a process of learning for public sector to work with private sector to start a consultative dialogue towards policymaking seem to have failed.

Though Pakistan wants to move forward it has a pull from within preventing progress and from moving forward. It also lacks capability at official level and may require additional technical support to develop the capacity at the academic level and at official and private sector level. But we know that "top-down" system has its strength though it may have weaknesses also.

\section{The Homogenous Vs the Dual Society - using Pakistan as Case Example}

$(B O X-I)$

Pakistan being a developing nation, in contrast to industrialized world, it is characterized as 'dual society' where co-exists a stagnant traditional sector along with the dynamic modern sector (a tug of war). This ends up in a poor quality culture owing to half-baked intentions and not being sensitive to customer satisfaction because of laid-back attitude. (Anonymous)

Pakistan has been constantly loosing its markets for its product. It has a chronic trade deficit and suffers from an image of poor quality and unreliable supplier of products. All of this means that Pakistan will face the prospects of continuing economic losses unless it faces the challenge. The problem is not one but many, but the three key issues are:

1. That Pakistan is operating with an obsolete trade policy that has no objectivity.

2. The implementation lacks an enlightened approach such as the need to have a marketing approach and hence the understanding of International Marketing. The Government lacks the will and ability to implement.

3. That there is no government support to help the exporters succeed in the fast paced highly competitive global markets. As a matter of fact the government and private sector have an antagonist approach. Further the government is unaware of the global commerce and how it is conducted.

It can be seen that Pakistan is confronted with the 'internal agenda' and the 'external agenda'. This is to say that under an 'Internal Agenda' Pakistan needs to focus on competitiveness of its industry, its highest quality at a most attractive price and the need to create cooperation between government, private sector and the workers to feel committed to a quality culture that should be export oriented and innovative in marketing. The second and third grade quality culture to meet the needs of the internal market should be abandoned and the internal market should be upgraded to international quality level.

The External Agenda would focus on expanding trade. This can be achieved by the negotiating strategy such as Plurilateralism, or flexible or tailored to deal with the 5 Economic Systems with the understanding as they are and not as we presume them to be or desire them to be. It would require an understanding of the economic system, its characteristics based on its culture, its politics, its level of technology.

There is no doubt that Pakistan is a sufficiently large market, moreover, it is the gateway to Central Asia and is the backyard of the Middle East. This gives it a central position among excellent market. Hence when adopting a tailored-trade approach it can adopt a parallel negotiation strategy. An approach of this kind of negotiation can proceed bilaterally, plurelaterally or multilaterally. It gives flexibility to negotiate with cooperative trading partners, even if others are not participating. But the momentum of successful negotiation attracts the uncooperative to join in. (As can be seen there is great emphasis on negotiation skills of the policy implementers).

Now comes in the size of Pakistan's market and Pakistan's neighbors market into play, since the benefit to trading partners is access to the market.

In self-interest, Pakistan should use this tool against those trading partners who have access to its market but do not import from it. The bilateral talks should lead to trade expansion. Pakistan's national interest lies in expanding trade and it should make it clear that if it is to allow import of tea say from Kenya, then Kenya must expand trade by importing their requirement based on bilateral agreement. A similar approach with the oil-exporting partners could be adopted. Further, down the road it can enter into plurilateral negotiations with EU member countries that are its traditional trading partners and negotiate expanded trade based on the market that Pakistan offers to them.

(Developed on the Concept of the Paper "Tailored Trade" Choate, Linger)

Iqbal M. Khan "Total Trade Policy Management \& Competitive Advantage" Proceeding of Pakistan Sixth International Convention on Quality Improvement, Nov. 2000 


\section{Singapore}

The first independent Singaporean government adopted an import-substitution strategy to improve the balance of payments. The small size of domestic market and scarcity of natural resources did not suit import substitution, however, this policy failed. In 1967 it was replaced by an aggressive, export-promotion strategy based on the creation of an industrial sector of globally competitive, labor-intensive manufacturing and assembly and by welcomed foreign direct investment. But government accelerated intervention in the economy, new laws controlled labor cost. To facilitate investment flows EDB opened its first foreign offices in Hong Kong, New York and San Francisco to woe MNC to operate from Singapore. It attracted immediately electronic industry. The economy produced results: the GDP growth averaged $10.3 \%$ per year between 1965-83. Per capita GNP grew at $7.8 \%$ reaching to $\$ 6300$ in 1984 . Exports grew at an average of $19 \%$ in the period $1966-82$ but being a tripled-based economy there was growth in finance \& manufacturing simultaneously. In 1997 the real GDP growth was $8.9 \%$, in 1998 it was $0.3 \%$, in 1999 it was 5.6\%, and in 2000 it was at $6.2 \%$. By end 1999 the reserves were US\$77.1 billion and per capita income was \$24,183. (Economist Feb 2000). By the end of this decade the Euromoney Magazine named Singapore the Second-best economic performer in the world and the competitiveness Report ranked it the most competitive of world newly industrialized countries. *Trade and Foreign Investment, In keeping with its duty-free history, Singapore after independence maintained very law tariffs on all goods and levied no capital gains tax. There were no restrictions on entrance to and exit from the Singapore economy for foreign investor or on repatriation of income and capital.

_ Singapore was one of the few nations where the sum of import and exports (including transshipments) was greater than GDP. This reflected the renewed importance of entrepot trade, which revived as political relations improved with Singapore's rapidly growing neighbors. Singapore's reserves of foreign currency reached S\$59 million in 1991, exceeding those of most other countries on a per-capita basis. The current account in the balance of payments turned positive in the mid-1980s despite a perpetual merchandize trade deficit.

\section{Malaysia}

Malaysia adopted the policy of export led growth and has been successful exporter of manufacture since late 1970s. However, even in 1990, primary goods were still 45\% of total exports. The real GDP growth in 1997 was $7.5 \%$, in 1998 it was negative in 1999 it was $5.1 \%$ and in 2000 it was at $6.8 \%$. By end 1999, reserves were $\$ 30.2$ billion and per capita income was $\$ 3,733$. The major exports had always been electrical and electronic goods throughout 1990 .

The principal change in the structure of Malaysian economy took place during the 1970s with agriculture falling from $23 \%$ to $18 \%$. Malaysia has been a successful manufacturer exporter since $1970 \&$ there has been an explicit policy of export-led growth. The major exports have been electrical and electronic goods and today its a major exporter of micro chips. One development in which Malaysia was a leader was in counter-trade as it was the first to introduce this in its trade. Malaysia offers an example of a country, which has attained its growth due to harnessing its resources and using regulatory environment judiciously. It has also maintained a policy of avoiding borrowings and its trade has not been financed by multilaterals. (A Strategy for Economic Growth).

5. Taiwan (The Making of a Miracle, Harvard Business School, Ravi Ramamurti 1998. HBS-9388-053)

Following an initial experiment with import-substitution policies between 1950 and 1960, the Taiwan government chose to pursue an export promotion strategy. it was decided to open up its economy, upgrade its consumer goods industry, promote labor-intensive industries. it had announced a 19-points Report Program "To improve the Investment Climate, liberalize, trade and further strengthen export promotion efforts". This program affected the government's fiscal, monetary trade and foreign investment policies.

\section{5. i Fiscal Policy}

The fiscal reform after 1960 extended 'tax holiday' for investment and for expansion and also allowed tax incentives for exporters. These policies allowed concession of differed import duties on plant and equipment. Industrial estates were developed all over the country, which were offered on incentives and under one-window operations. The formal banking channels were encouraged. Despite deficit budget the policy was implemented for long-term benefits.

\section{5. ii Trade Policy}

Trade Policy offered Export Incentives by offering low cost loans to finance the entire manufacturing cycle. The industry associations also developed export promotion schemes for the exporters and penalties for not maintaining the export norms.

Finally the Foreign Investment Policy was introduced to attract foreign investment: It guaranteed that foreigners' assets would not be nationalized. It also promised to check labor demands. But it was also supported by USAID which encouraged American Investment in Taiwan. The break come through a huge investment by US firm the General Instruments which created the agglomeration effect in Taiwan.

\section{5. iii Export Processing Zones}

Export Processing Zones produced an export of $\$ 450$ million by 1975 . The significant feature of the Taiwanese economy was the participation of thousands of small enterprises in the export boom that Taiwan was 
experiencing in the late 1970s. Almost 50\% of the exports were routed through Japanese or American companies or with the assistance of foreign companies (Remamurti 1988, Harvard Business School).

Its real GDP growth averaged 9\% during 1965-83 \& per capita grew at 6.8\% and stood at \$3,070 in 1984 . Exports grew at an average rate of $20 \%$ per year between 1966-84 and its share in GDP was 58\% in 1984. In 1997 real GDP growth was 6.8\%. In 1998 4.7\%, in 1999 it was 5.5 \% and in 2000 it was at 6.5\%. By end 1999 reserves were $\$ 106.2$ billion and per capital income was $\$ 14,206$. (Economist Feb 2000)

\section{South Korea}

In its first five-year plan (1961-66), the new government developed an export promotion strategy based on the creation of a labor-intensive manufacturing sector. Other changes included devaluation of the Won and establishment of a floating exchange rate, trade liberalization with preferences for imports of machinery and intermediate goods, and battery of tax, credit, and tariff incentives for manufactured goods. Korea managed to grow at $9 \%$ per year during this period, exceeding the plan's target of $7.1 \%$. Its GDP growth averaged $8.5 \%$ between 1965-83 and per capita GNP grew at 6.7\% and stood at \$2000 in 1984. In 1997 real GDP growth was $50 \%$, in 1998 it was negative. In 1999 it was $9.5 \%$ and in 2000 it was at 5.5\%. By end 1999 reserves were $\$ 69.7$ billion, per capital income was \$10,152 and exports were \$ 141.02 billion. (A Strategy for Economic Growth)

\section{Hong Kong}

As with the other NICs, Hong Kong's growth was externally oriented. Exports grew at an average yearly rate of $20 \%$ between 1966 \& 1981, and in 1982 they accounted for almost 90\% of GDP. It also became the major offshore banking center of all Asia. The service sector and manufacturing sector accounted for 65\% of GDP in 1982. In 1997 the real GDP growth was 5\%, in 1999 it was $2 \%$ in 2000 it was at $5.4 \%$. By end 1999 reserves were \$ 96.3 billion and per capital income was \$24,440. (A Strategy for Economic Growth)

\section{Conclusion from the Experience of the Asian Tigers}

The purpose in quoting these oft quoted examples of Singapore, Hong Kong, South Korea and Taiwan is to establish the fact that the trend of economic growth is through focusing on trade. As has been seen that between 1950 and 1975 the volume of trade expanded by as much as 500\% against an increase of global output of $220 \%$. This is the cross-road of opting for economic growth through trade and there is a lot to learn from them. The example cited is indeed the economic growth of the century. This region is home to about 500 million people and has a combined GDP of more than $\$ 700$ billion. (Economist Feb 2000). It had a large young population, highly educated and disciplined after decades of policy management and implementation.

But with the turn of the 90's there were new entrants in the international scenario. The role of policy towards trade had become significant. Two conclusions emerged by examining studies of these developing countries: first that policies can matter to trade, second, that the way in which they effect trade through trade the rest of the economy, depends on how exporters and potential exporters respond to them and how government learn to intervene optimally. The idea being generated is the art of implementation of Total Trade Policy Management at the optimal level. (Page 1994)

It also shows that, there is close relationship between economic growth and cooperation between government and the private sector.

\section{E. THE TAILORED TRADE POLICY}

\section{A New Theory of Trade Policy Concept}

Classical theory explains the success of nations in particular industries based on so-called factors of production such as land, labor and natural resources. Classical theory, however, has been overshadowed in advanced industries and economies by the globalization of competition and the power of technology. A new theory (policy) must recognize that in modern international competition, companies compete with global strategies involving not only trade but also foreign investment. What a new theory (policy) must explain is why a nation provides a favorable home base for companies that compete internationally.

"A new theory (Policy) must move beyond comparative advantage to the competitive advantage of a nation. It must reflect a rich conception of competition that includes segmented markets, differentiated products, technology differences, and economies of scale. A new (policy) theory must go beyond cost and explain why companies from some nations are better than others at creating advantages based on quality, features, and new product innovation. A new theory (policy) must begin from the premise that competition is dynamic and evolving; it must answer the question: Why do some companies based in some nation innovate more than other? Why do some nations provide an environment that enables companies to improve and innovate faster than foreign rivals"? (Michel E. Porter)

\section{The Tailored Trade Policy and the Competitive Advantage Management}

"Tailored-Trade" was developed as a new concept of trade policy at Harvard (Pat Choate, Juyne Linger). The concept of Total Trade Management Policy has been based on the concept of Choate and Linger. In quest for a policy, meeting all standards of quality to be able to prepare firms to compete, hence Develop Competitive Advantage, which is the other aspect of this paper and the concept. Hence competitive advantage has to be 
gained in every aspect and every step of thinking and this is why it was considered calling this concept as Total Trade Policy Management.

\section{F DESIGNING TRADE POLICY}

In our hypothesis we have seen that globalizing trade policy is a now a norm. One of the evidence available to us is from another source other than the WTO. This is the format for a trade policy as promoted by OECD \& UNDP.

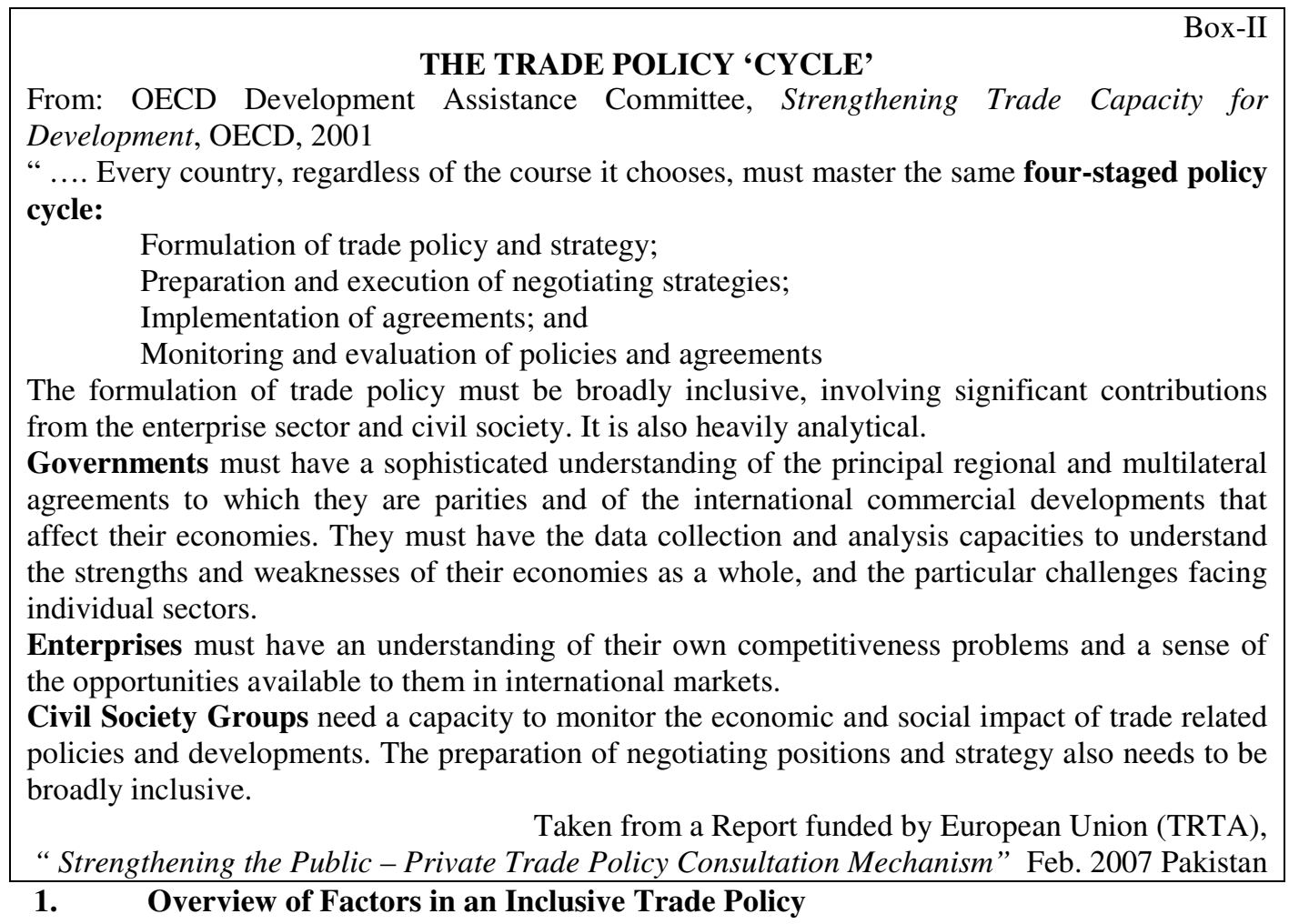

There are certain other realities to recognize before making a policy. Some of these hard-hitting realities are: (See Economist Feb. 2000)

1. That this is an age of global interdependence - in fact a borderless world.

2. That everything is globalized e.g. finance, technology, communication, research, product development, investment, service and marketing -and new Trade.

3. That the world has been divided into 5 broad characteristic economic systems and that there is a debate for fair vs. free trade.

4. Half the world has moved towards managed trade and the other half has moved in favor of free trade.

5. The emergence of WTO is the proof that the western world today favors "managed trade" as the only way to meet the economic challenge of the next century or so, as an outcome of their experience over this country. Whereas Comecon-countries want to be members of a free trade society.

6. That it is in the interest of the country to develop its trade policy. This self interest and a combination of understanding its markets, is what we term as Tailored Trade Policy as explained below.

It is essential to have negotiating capabilities and flexibility, based on Plurilateralism, to expand trade with other nations. That a Tailored-Trade Policy is one which is based on recognizing the different economic systems and their demands and dealing with them as they are, rather than as we wish they were and that we need experts not generalist to implement such a policy. That is the basic tenant of this policy implementation strategy.

Whereas trade is the route to economic development, but trade policy taken in isolation, will have no clear-cut impact. For economic growth, prudent intervention by government is required to allocate resources increasingly towards favorable industry that give competitive advantage to quality products at highly competitive prices in the international markets. This is the other basic tenant of the policy.

Emulating the example of MITI and using it as a benchmark would be prudent.

That MOC be revamped, on the experiences of MITI and its human resource should be upgraded.

2. Towards Inclusive Trade Policy

A new agenda has emerged in voicing the advocacy of trade. 


\begin{abstract}
"It ranges from small business coalitions to non-governmental organizations (NGOs), media, international agencies, academics, big business and more. All these voices are needed to shape a more inclusive trade policy and move closer to achieving the development promise of the Doha Development Agenda". Natalie Domeisen, ITC, International Trade Forum. Issue $1 / 2006$.
\end{abstract}

All this poses a great challenge for any kind of administration. How does one achieve consensus and a balance with such diverse interest. More people now take part in the trade debate and are very conscious of the benefit of open trade. She points out that inclusive trade policy has witnessed issues such as:

"Social justice, retaining workers, exporting jobs, keeping local cultures alive, colliding forces of nationalism and globalization, afflictions of global capitalism, nationalist resurgence and protectionist backlash".

She calls it an 'emerging trend' - and it will eventually evolve trade truly as a force for development. The natural outcome of these developments is to adjust these factors into the Trade Policy Paradigm.

Every nation is weighing its option viz-a-viz WTO and reconsidering a repositioning of strategy. These are the forces of the world. It would be better to be in the main stream to accept the world as it is. After this acceptance and recognition to proceed to draw up the trade policy and the strategy tailored to implement it.

"If we want to understand the post-cold war world we have to understand that a new international system has succeeded it-globalization". (Thomas Friedman 1999)

The world today is a border-less world and that we are global citizens. We need to understand what $\mathrm{s}$ Globalization of Markets. We also need to know the International Marketing aspect.

Stephane Garelle, Professor at IMD says in his "The Four Fundamental Forces of Competitiveness" that there are two facets of competitiveness; companies and nations. Within a nation, the fundamental role of companies is to create economic value added. This process requires capital, technology, labor, natural resources, etc.... Modern economists analyze company competitiveness from the angle of strategy formulation, product development, processes or structure. The goal of the company remains wealth creation.

Companies, however, do not operate in a vacuum. Their performance depends heavily on their national environment....In fact, the process of wealth creation is so critical to the prosperity of nations that, some opted for nationalization and others left wealth creation in private hands - free markets. Certain environmental facts are conducive to development and competition of companies, and others may be detrimental.

They say that the New World was born when the Berlin wall fell in 1989. The global economy is still finding its bearing "technology, properly harnessed and liberally distributed has the power to erase not just geographical borders but also human ones (Advertisements).

Theodore Levitt says:

"The difference between the fox and the hedgehog is that the fox knows a lot about a great many things, but the Hedgehog knows everything about one great thing”, The multinational corporation knows a lot about a great many countries"....and adopts not recognizing how the world is ready and eager for the benefit of modernity". "By contrast, the global corporation knows everything about one great thing. It knows about the absolute need to be competitive on a world wide basis... Its mission in modernity and its mode, price competition, even when it sells top-of-the-line, high-end products. It knows about the one great thing all nations and people have in common, scarcity" - If this be true then the human resource factor will have to be trained \& skilled and upgraded to feel the pulse of the global market and to be able to compete in its area of strength". (The Globalization of Markets)

\title{
3. Upgrading the Ministry of Commerce (MOC)
}

After all, in this dynamic scenario, what should a trade policy seek to adopt? Perhaps the first step would be to revamp the Ministry of Commerce and attract to it the professionals and specialist on trade who have been working in the WTO, or UNCTAD or World Bank. (Since every nation is represented in these multinational agencies, we get the benefit of highly trained professionals. It would cover a great distance required to train them at home). This is where we need to study the example of MITI of Japan. Attract the talent back to the country by giving them matching benefits. We can take the step to protect this ministry from penetration from other quarters and other 'Groups' or category of personnel who do not have sufficient experience of trade and International Market. Thus we create a "market-minded government", which would also be in close contact with the business community through the Federation, and the Chambers of Commerce and Industry Associations.

The emphasis will have to be to rely on professionals who should stick to these areas of specialization for a lifetime period. It boils down to talent hunt and to man the MOC with the best among the best to fight our ways in the international markets. The might of Nations is now measured in the field of international trade - hence how can a national afford to have a week Trade Policy. Speaking at Harvard University in 1943 Winston Churchill observed "the empires of the future will be empires of the mind". Since then it has been considered that the battles of the future will be the battles for talent. How can a nation fight its war or its battles by loosing its brainpower to other countries? "Attracting and retaining" talent should be the number one priority. (See 
Economist October $\left.7^{\text {th }} 2006\right)$

\section{Creating a Market Minded Environment}

It is easy to lose a market driven focus and to do what is easy and convenient versus what the market wants and needs. Each market has to be defined. Hence the Government through its enlightened MOC should:

1. Control protectionism sentiments at home, with caution and self-preservation like the Chinese are doing.

2. Open foreign markets to imports cautiously. (Again learning from the Chinese)

3. Help its exporters to compete in foreign markets and a fund should only be used to develop new markets or introduce new products.

4. Help the domestic economy to be highly competitive and adjust to the changes brought by shifting patterns of trade.

5. Develop Domestic Commerce to absorb the growth in trade.

6. Maintain a single tier foreign currency rate between official and market rate.

7. Assemble a formidable hiring machine to find talent and retain talent.

All of these are linked and need consideration and planning and it should resort to reciprocity. A truly marketing approach would be a co-operative effort to promote trade by Government and business partnership or in the true sense the public-private-partnership.

Strategy development dialogues should be externally oriented and the Ministry of Commerce should develop superior ability to generate market intelligence and anticipate market response \& customer perception. It should align strategy with structure and human resources. An extensive undertaking to train and develop a special cadre of people for the Ministry of Commerce.

A market minded government would also wish to distinguish carefully between the sort of help that is designed to capture benefits for the nations (rents) and the prudent allocation of resource. This kind of policy would work towards helping its exporters to compete in the foreign markets. Such a government does not consider helping the private sector as if it is doing favor to an alien but grooming a member of its team that is to win against a rival. It will go from boosting productivity to increasing opportunities for its exporters. Moreover, the rule of the game with WTO is that the teaming of public and private is essential to represent the interest of the country. With opportunities at home running dry, the hunt for talent has to spill over in the Multinational Agencies. Obsession with talent is no longer confined to blue-chip companies; it is found now in public agencies and in government. It has gone global. (See Economist October $7^{\text {th }} 2006$ )

In the fourth scenario the market-minded government would grant temporary transparent protection with preannounced rate of withdrawal to industries under stress of new shift. In this way the objective is to build up its comparative advantage and it can also solve such dilemma as MFN status for countries that have a historical antagonism between them.

It can be expected that with such a type of policy, rule-based system liberates market forces, leaving them to determine pattern of trade.

\section{The Official and Kerb Rate of Foreign Currency}

$(B O X-I I I)$

The decision of the Pakistan Government to freeze the Foreign Currency Accounts in 1998 has been responsible for shying away foreign remittances \& foreign investment. The other repercussion has been the lack of confidence in the policy of the Government hence there has also been the flight of capital since then. It has also resulted in enhancement of remittance coming through the hundi system. The export proceeds have fallen in value terms to as much as $25 \%$. The market rate of currency is an incentive for \& hundi system in the hands of the private citizen. To boost export earnings the central bank will have to review its policy in terms of tworate policy.

A bold decision is required \& consistency of policy. Foreign remittances will only come in $\&$ exports proceeds will only rise if the kerb rate \& official rate is same. Beyond that other policy measures are required to control free flow of foreign currency.

Iqbal M. Khan "Total Trade Policy Management \& Competitive Advantage" Proceeding of Pakistan Sixth International Convention on Quality Improvement, Nov. 2000 5. The Role of Marketing in a Trade Policy

As early as 1968, Peter Drucker has been writing about entrepreneurship. He says "The Age of Discontinuity" that fifty years before the out break of World War I it was the 'Heroic Age of Invention' which be terms as "Heroic Age of Entrepreneur". (The German's would term these the "Years of the Founders"). Drucker was convenienced that we are entering again an era of entrepreneurship. He says that this is an age of rapid change and hence technological strategy is essential for success and survival for an industrial nation. But what is essential to realize is that:

"No one in an age of rapid change can possibly hope to produce all the technology that is 
needed, not even in one's own area. Not even the biggest company - and not even the most powerful country".

He further emphasis that:

"Today everyone will have to accept that no one can possibly be self-supporting in technology. Everyone will have to learn what to concentrate on, but also what to bring in from others, and at what stage."

He quotes the example of the Japanese who have learned how to look for the emergence of new technologies and how to acquire it, but have not learn to market it, to gain the greatest possible yield.

On the other hand he quotes the example of Sweden, which has understood the:

"Need for a technological strategy that is appropriate to a small country where available resources have to be concentrated on filling gaps in a few area rather than on providing the main advance. Now she has become, in terms of per capita output, Europe's leading industrial economy and has attained a standard of living second only to that of the United States".

Another example he gives is of Great Britain which has failed to understand the market and its dynamics. Despite its advanced technology gains in the areas of:

"Antibiotics, radar, and the jet engine, to name only a few, are all British in origin. The computer, too, owes a great deal to British technology, and so does the atomic reactor. Yet in none of these have the British reaped where they sowed and cultivated failure to understand the market and to be concerned with its dynamics, is clearly a central reason".

The conclusion that one can arrive from these examples is that just as a company needs an innovative marketing, so does a country needs Innovative Trade Policy. Hence an objective of the trade policy would be to create a Market Minded Environment and for the Ministry of Commerce to because a truly Market Minded institution of trade.

He further emphasizes that "the era of innovation and technological change makes great demands on government policies". He goes on to explain some important aspects such as to allow mobility of manpower and capital. These mobile resources of economy must be able to move into the productive allocations. In this age of rapid change, the greatest productivity, as he pointed out, was in 'knowledge work' and not in 'manual work'. He has indicated the importance of knowledge management as early as the 1960s. He had also suggested that capital should be allocated to knowledge economy as it would yield a high and rising standard of living. He then goes on to cite the conclusion of a study made by sixteen American Leading research administrators from large corporations as Xerox, that, small firms have been more innovative then large. Hence his conclusion was that small enterprise should be facilitated by the support of policies. But the most relevant observation by Drucker in designing a policy is that:

"Government will have to learn to look outside and to develop their domestic policies on the basis of the indicators of the international economy using the international economy as the yardstick. The smaller countries, Holland, Switzerland and Sweden have had to do this all along. International trade and international markets dominate their economies anyhow, whether they like it or not. But of the large countries only Japan has since 1950 steered by the international economy. This is undoubtedly one of the central reasons for the phenomenal performance of the Japanese economy".

The phenomenal success of Japan has been only because it took it cues from the world economy and its trends and developments. Its "industrial policy followed the export oriented industrialization" and noticing the leading edges of technology and economy. It was able to anticipate what the new industries will be and where resources have to be allocated most productively. Then he goes on to compare Japan and Great Britain. Of the two island economies, the British was not only the greatly more developed, but British industry had come out of the war a good deal stronger then it had entered it:

"Yet twenty years later, it is Japan that has forged ahead while Britain has fallen behind. One of the main reasons for this is that Japan made the world economy determine her economic policies, whereas Britain made her economic policy serve principally to maintain here traditional, domestic economy. It is fashionable today to blame the 'Welfare State' in Britain. It is true that Japan has not been anywhere near the social provisions that Britain - or for that matter, Germany, or the United States - has for her workers and farmers. But compared to Japanese productivity and per capita income, Japanese welfare provisions, though organized in very different fashion (largely as customary rather than contractual employee benefits), are at least as high as those of the British Welfare State. Japan has welfare rigidities, such as her 'lifetime employment', which go far beyond any welfare burden the British economy might carry. The real difference is one of fundamental attitude, outlook and policy".

There are many lessons that can be learned from Drucker in devising our trade policy. He has suggested that entrepreneurship should be supported and small firms should be facilitated for their innovation generation. He 
advises that it is essential to be "market minded" economy and that its Ministry of Commerce should be an institution to develop a successful Trade Policy. A successful nation would be able to move into productive allocation of resources after noticing the leading edge technology and new industries of the world economy. Hence it was important to recognize the emergence of the knowledge economy and that it was the most productive allocation of moveable resources.

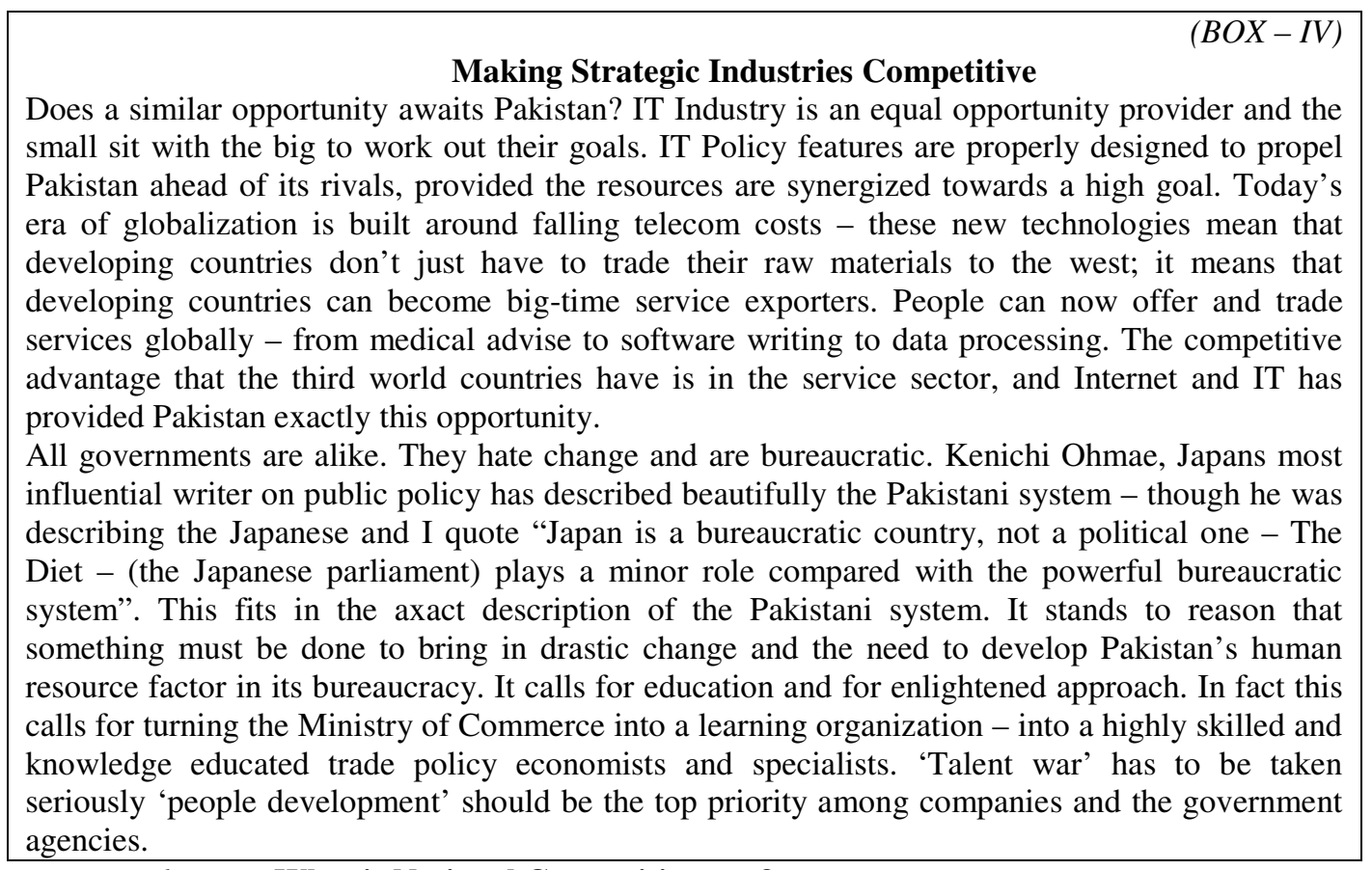

\section{What is National Competitiveness?}

The modern concept of competitiveness has developed from the profound work of Peter Drucker and Michel E. Porter (Harvard Business School Professor). Both economist and public policy writers have emphasized the significance of innovation and constant up-gradation. Both have also emphasized the underlying fact that for success in the global market, it is important to realize that macroeconomics and microeconomics. Both have to be taken simultaneously for competitive advantage. Michel Porter came up with his book "The Competitive Advantage of Nations" in 1990, which developed the concept that the determinants of National Competitive Advantage were the Factor Conditions: the Demand Conditions, the Firm Strategy, Structure Rivalry and the Related and Supporting Industries. He calls these as the Diamond of National Advantage. He says that basis of competition has shifted to the creation and assimilation of knowledge. These factors have been the common factors that we find in all literature on trade, economic development, policy and national prosperity. He says:

"National prosperity is created, not inherited. It has not grown out of a country's natural endowment, its labor pool, its interest rates, or its currency's value, as classical economist insists"

His book is the result of a study on the leading trading nations to study the pattern and policy of competitive success. While he goes onto explain in detail the factors that have propelled some successful trading nations, he brings home the fact that it is companies and firms that bring competitive advantage to nations. Hence what needs to be done is to create an "environment in which companies are born and learn how to compete". These are in fact the policies and "condition in the nation governing how companies are created, organized and managed, as well as the nature of domestic rivalry”. (Porter)

Applying these concepts to Nations to develop the Competitive Advantage he however, cautions that as yet there is not even an accepted definition of the term "Competitiveness" as applied to nation. But since he has worked on this theory in 10 leading Trading Nations (which in fact accounted for 50\% of total world exports in 1985) with a variety of government policies, social philosophies and national environment, he has developed the concept of National Competitiveness. The previous analysis of national competitiveness had focused on single national or bilateral comparisons - but his study sought to separate "fundamental forces underlying national competitive advantage". An excerpt from his article in his book "The Competitive Advantage of Nations" entitled "National Competitiveness" is being reproduced to establish that such factors will be fundamental in developing a Trade Policy. The article is almost a treatise on the subject and merits an important position in formation of a Trade Policy.

"National competitiveness has become one of the central preoccupations of government and industry in every nation.... While the notion of a competitive company is clear, the notion of a 
competitive nation is not..... Some see national competitiveness as a macroeconomic phenomenon, driven by variables such as exchange rates, interest rates and government deficits. Others argue that competitiveness is a function of cheap and abundant labor..... Another view connects competitiveness with bountiful natural resources..... More recently, the argument has gained favor that competitiveness is driven by government policy: targeting, protection, import promotion and subsidies .....

A final popular explanation for national competitiveness is differences in management practices, including management-labor relations.... Clearly, none of these explanations is fully satisfactory; none is sufficient by itself to rationalize the competitive position of industries within a national border. Each contains some truth; but a broader, more complex set of forces seems to be at work".

"What is a "Competitive" nation in the first place? .... The only meaningful concept of competitiveness at the national level is productivity. The principal goal of a nation is to produce a high and rising standard of living for its citizens. The ability to do so depends on the productivity with which a nation's labor and capital are employed.... Sustained productivity growth requires that an economy continually upgrade itself, a nation's companies must relentlessly improve productivity in existing industries by raising product quality, adding desirable features, improving product technology, or boosting production efficiency.... No nation can be competitive in everything... Seeking to explain "competitiveness" at the national level ... We must focus not on the economy as a whole but on specific industries and industry segments. We must understand how and why commercially viable skills and technology are created, which can only be fully understood at the level of particular industries".

\section{G. THE GLOBALIZATION OF TRADE POLICIES}

"Globalization is a fundamental transformation in societies that is enabling individuals, corporation and states to influence actions around the world -- faster, deeper, and cheaper than ever before. Like the industrial revolution of the $19^{\text {th }}$ century - recombining economic \& social forces". Worldwide Pascal Lamy -- Director General, WTO

Economic development today is as much subject to globalization as any other aspect of life. We have just seen that the past three decades have became influenced by trade and by trade policy. These are fundamental changes in the pattern of sectoral development and type of development policy. We have also seen that the choices of Development Policies are linked to the policy of trading partners. For example the policy decisions of the importing countries have a significant effect on the pattern of exports. This in turn will also affect the country's approach to economic development (Page 1994). The reverse may also be true. Nothing can best explain this phenomenon then the term 'Globalization'. The other feature of this globalization is seen in the development of lobbying by the trading partners. International lobbying by the governments have became a norm, so as to seek, the MFN status or to waive barriers to trade or to gain access to markets. Standardization of standards, of processes and products, all have led to globalization. But the most influential feature that may dominate the future trends is the powers vested in the WTO to look into the Trade Policy of member nations. In going for a policy of globalization of its products and markets, Nations themselves have had to submit to the globalization of its Trade Policies to be sensitive to the changes taking place in the economic policies of its trading partners or would-be-trading-partners. The meeting place and the cross roads of all trade policies is the WTO and all Ministers run to this Mecca to globalize their trade policy. If this is not done the ultimate end would be bleak.

\section{The Globalization of Textiles}

$(B O X-V)$

This world is full of animals and each survives in spite of being sworn enemies. The way they survive is by developing some competitive advantage over the fox or the lion, or the rhino, or the tiger or the snake or the 'mongoose'. Hence Pakistan too can survive in this world of foxes and tigers by being a hedgehog and developing skills and superiority in the area it truly has strength.

Once we have built our base on sound and durable footings we can think of strategies to diversify. We don't realize that in the very weakness of our economy - that we are heavily dependent on one product, up to $60 \%$, of our trade, we can find strength and convert this weakness into our superior strength. We should become the world's Textile center, its "Silicon Valley". Hence flow of capital and resources would flow in this direction leading to R \& D in all its areas. All we need is consistency and strategic planning.

The new commercial reality is the emergence of global markets for standardized consumer products on a previously unimagined scale of magnitude." The world's preference structure is 


\begin{abstract}
relentlessly homogenized. Almost, everyone everywhere even in the remotest corner of the world wants all things they have heard about, seen, or experienced via the new technologies such as video, TV, or satellite. Its not difficult to realize that Pakistan has acquired textile technology and must continue to acquire it from all corners of the world. It should not be difficult to understand that the production of textile products can be standardized to meet the taste and consumer preference existing all over the world - because modern communication is a strong influence. "It has made peoples eager for modernity."

Gone are the accustomed differences in national or regional preferences". It is the textile fabric of France, Korea, Japan, USA or Pakistan that will be used by the traditional dress of Africa, Middle East, Malaysia, Japan, Central Asian or Bangladesh. The textile products will be sold and will compete in all these countries in the some way everywhere as if these were a single entity. This free market competition would result in low relative cost.

Pakistani companies would then start competing on the basis of appropriate value, the best combination of price, quality, reliability and delivery for products that are globally identical with respect to design, function and even fashion".

By focusing on textile industry Pakistan will have to adopt globalization policy. In this manner it would also promote the development of ancillary industries. It would promote the industrial clusters and foster competition within, which in turn would improve quality and reduce cost. It would generate innovation and creation leading to engineering designing and support institutions such as education, research and development centers so forth. Thus it would also vindicate the 'Porter Model'.

To expect all this from the textile industry sector would not be wrong. After all the entire nation contributes to the growth and flourishing of this industry. As a matter of fact 10 year down the road Pakistan should be the World Textile Center. Pakistan should be the producer of the modern textile machinery and engineering. If Uzbekistan is being considered to be the biggest supplier of textile industry to the world by the turn of the Century, then surely Pakistan has something serious to think of. It would also be the responsibility of this industrial sector in Pakistan to focus on the agricultural aspect of cotton textile. Agriculture research should improve the variety of the crop. If India can start bioengineering on the silk worms to produce colored silk thread, biogenetic engineering can do the same to the cotton crop. If any one feels that this cannot be done, he does not know the revolution of biogenetic engineering.

Without doubt this one industry, which we can backward integrate, forward integrates, undertake down stream or upstream development and have a complete economic growth pattern. By accepting the fact that there will always be demand for textile and always scarcity of these products, we are thinking marketing. By adopting strategies to take advantage of the international markets we are again thinking marketing.

By recognizing that High quality and Low costs are not opposing postures but are compatible twins, we are again thinking marketing. International Marketing is not the domain of corporation, companies or marketers, but in all its aspects and dimensions, it is the purpose of every country and has to be the corner stone of its Trade Policy.
\end{abstract}

Iqbal M. Khan "Total Trade Policy Management \& Competitive Advantage" Proceeding of Pakistan Sixth International Convention on Quality Improvement, Nov. 2000

\title{
H MANAGEMENT ASPECT OF TRADE POLICY \\ 1. What Kind of Policy Would Matter
}

The questions of the role of the policy (policies) towards trade in developing countries can be studied by examination of their trade policies. They offer us lessons to understand what policy means to success and direction. The examples of Japan and the 4 Asian Tigers have been taken to show how an export-led economy has contributed to economic growth through trade. However it has to be kept in mind that each country's own trade policy, and in particular "trade liberalization" took central importance. The policies of its trading partner must not be treated as secondary problems. Hence it must be understood that there is interaction directly between the trade policies of a country and those of its trading partners, and different perceptions of these.

This brings us to the conclusion that we have to look towards new direction to adopt a trade policy. It is of course the subject of Public Policy and needs pondering over all issues and thrashing out all alternative. It needs to examine a lot of experience that exists around us and perhaps to look for a non-conventional approach to our policy.

In selecting our approach we have to pick a path that offers solutions to our problems. Something that can develop the core-competence and help develop a culture to think strategically. One such policy approach is the Total Trade Policy Management, for competitive advantage, which this paper has argued in favor of and used the 
various experiences and knowledge of the subject to propound this theory of trade policy. In its true sense the policy would need to be Global in order to be sensitive to the changing environment. It will be the product of the new MOC which will be truly a learning organization.

\section{The Five Economic Systems}

The basic tenants referred to earlier are necessary to develop competent Human Resource for a @Total Trade Policy Management concept. Now to be able to make an effective Trade Policy the foremost objective would be to understand the economic environment that we are living in today. Some economists have pointed out that there are 5 types of competing economic systems and they can be described as follows:

1. The centrally planned model (like the Soviet Union, China, Central Europe and Central Asians).

2. Mixed economy model (France, Sweden, Germany, and other Europeans)

3. Developing economies model (Mexico, Latin American, African, South Asian).

4. Plan-driven economies model (Japan, South Korea, Taiwan, Singapore, Hong Kong).

5. Free Trade Economic Model - USA, Britain, Austria, Canada. The Anglo-American System. These five economic systems have been identified based on 4 dimensions, which have be enumerated below:

1. The role of Government in the economy

2. The ownership of the industry.

3. The relationship between process and results in the system

4. And how trade is conducted to meet the challenges of the global competition having trade sensitive fiscal, monetary, and exchange rate patterns.

3. The Development of Human Capital

"Talent war has to be taken seriously. "Attracting and retaining" talent should be number one priority. It is one of the mark of a sophisticated society that it rewards a wide variety of different talent". (See Economist October $7^{\text {th }} 2006$ )

With such a complex world to deal with, it would be required to develop in the Ministry of Commerce (MOC) and its human resource factor specialist in each of the five areas. These specialists would be groomed and acculturated to the system of each economic system. Besides, these experts should be trained to address Trade comprehensively imports; exports, investment, and competitive practices and be allowed to stay in their region of expertise for a life period. "Management talent has become more important to a much wide range of (agencies)". Talent has been defined as brainpower - the ability to solve complex problems or invent new solutions. Focus will have to be on knowledge workers within MOC and trade policy workers. The Economist also quote Lee Kuan Yew of Singapore "Trained talent is the yeast that transforms a society and makes it rise". Talent sometimes comes in unexpected guises. (Economist October 2006)

\section{CONCLUSION}

\section{Conclusion}

Eventually with the Total Trade Policy Management being implemented the pieces of the entire economic policy fall in place. It can only be achieved if the Ministry of Commerce becomes a learning organization and becomes market oriented when designing the policy and developing an export-led economy. Its focus being export promotion. The competitive advantage is built upon if the resources are judiciously managed. The industrial policy the financial policy, the monetary policy, converge on the issue of trade balance. It eventually pays dividends as have been proved by the East Asian Miracle and the Asian Tigers - This in spite of the Asian crisis. Global business environment and new technology also contain threats. Competitive advantage changes rapidly. There is a revolution in services. There is also a visible huge increase in number of deregulating economies. This is in the economics of the Internet age and we need to adopt at the Internet speed. It is being said that being first mover is of critical importance. The question arises that, is Pakistan nimble enough to cope with these threats? In brief the following needs to be understand and done based upon the analysis;

1) Favorable regulatory environment

2) Massive investment in human capital development

3) Diversity of economy decision-making.

4) Economic models need to be changed as in China, Korea \& Singapore and all of this is happening because of pressure from:

a) Trade opening

b) Globalization

c) Internet \& e-global accessing \& networking

d) World Trade Organization 
I. CASE STUDY OF A TOTAL TRADE POLICY MANAGEMENT: Recommendation for Pakistan as a case Model.

\begin{tabular}{ll}
\hline & $(B O X-V I)$
\end{tabular}

\section{I. i Implementing Total Trade Policy Management}

The question of implementation of trade policy measures in any developing nation should be a matter of looking forward with a globalized Trade Policy approach. If applied to Pakistan it should consider following implementation strategies. Its replicability to other developing countries can be as deemed necessary.

\section{I. ii The Trade Ambassadors}

Applying the concept of the Trade Ambassador.

" The Center of Gravity of today's foreign policy should be trade economics and not politics. Hence, to achieve this we need to develop territorial commanders to be know as 'Trade Ambassadors' to promote Pakistan all the time. The Trade Ambassador is opposed in terms to Economic Councellors. He should be considered apart from the diplomat who represents our country and comes from the diplomatic core. The Trade Ambassador should belong to the Ministry of Commerce. In this way the MOC becomes an elite Ministry - demanding respect

They ought to be trained at a The Trade Academy to be organized and run jointly by private and public sector. The members of this core should be from private and public sector. The Academy can be set up with the exporters' funds and it could be advised by aboard of governors and specialists and experts from institutions such as; ITC, UNCTAD, CBI, GTZ, Singapore Export Development Board etc.

The important aspect would be to spread them about in all the target markets of Pakistan and each Trade Ambassador should be the expert on the region and economic system he is working in.

\section{I. ii The Trade Academy}

The Academy can be set up with the exporters funds \& be manned by specialists \& experts from ITC, UNCTAD, CBI, GTZ, JETRO, Singapore, Malysia and so forth. Besides these specialists, there should be a talent hunt for Pakistan's in international agencies to attract them with incentives to Pakistan.

Diplomacy has changed dramatically since the end of the cold war. The traditional education in diplomacy, emphasizing history, politics, international law, is no longer alone adequate for our world. It has become imperative to also understand international business, trade, and communications. Conversely those involved in international business, international negotiations, trade promotion and commercial counciling are now diplomats, facing a world that necessitates an awareness of history, politics and international law and Trade Economic. Hence we are now producing Trade Ambassadors and hence a new shift in the Paradigm is being suggested and an approach to creating the Trade Ambassadors.

The Academy should take up such issues as its curriculum and give guidelines on following issues: a list is given below:

a. WTO and its implication

b. Regional blocs and their imperatives

c. The art of international negotiations

d. Child labor, Environment issues (ISO 14000) human right issues, patients and copyright issue, IPR ban of AZO dyes and chemicals, dumping and anti-dumping.

e. ISO 9000 standardization, harmonization, CE marking, classification of products by activities (CPA) binding origin information (BOI), eco-labeling.

f. The Academy should also be able to give guidelines on what position must be taken on all major international forums against discriminatory position taken by big powers on key issues to Pakistan.

g. The Academy should make it a point to be represented in international forums as 'full dialogue' partner to discuss changes in international political and economic trends, through these Trade Ambassadors.

h. The Academy should research on all regional blocs and give guidelines to adopt for bilateral, plurilateral trade or multilateral trade.

i. International Trade Economics \& Investment should be a regular feature of its education which should also include: -

j. International Finance

k. Foreign Policy and International Politics 


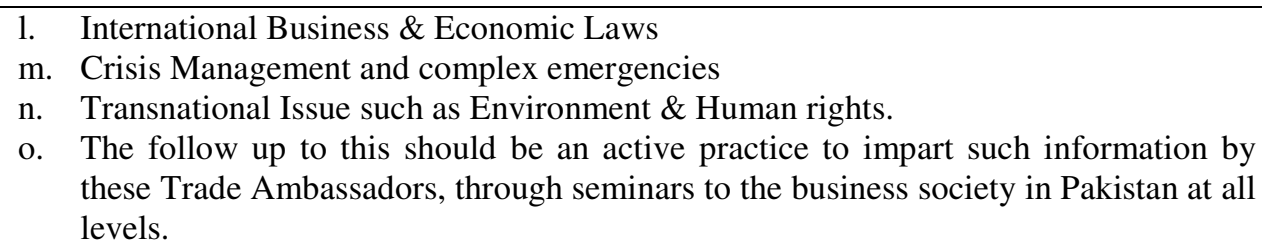

This would lead to confidence building owing to the sharing of knowledge with the people. It would also be a proof of proper utilization of funds deducted from the exporters. None of this fund should be allowed to be spent without proper sanction from designed bodies of the business society.

It is also imperative to understand and be able to protect viewpoint, which again can be developed at the Academy. If the rules of WTO go against Pakistan's social norms, it should take up. Marketing of the Nation and national interest should be promoted in all conceivable and respectable ways; image building should be the norm of all training and education.

\section{I. iii The Trade Bank}

In the modern world there is a very significant function of development banks in formulating and devising policy as was the case in Japan. Hence there is the emergence of Specialized Banks, that cater to industry or agriculture or SMEs or micro credits or house building. There are also specialized banks that cater to textile industry. Therefore in order to implement an export-led economy and develop competitive advantage, one vital link is the Export Import Bank (EXIM Bank). Most EXIM Banks are government held institutions and though this leads us to back-track our step in privatization we need to have an EXIM Bank - "There are significant benefits to gain from ..... to ensure that at least the policies of functional departments are coordinated and directed at some common set of goals" (Michel Porter).

"An Exim Bank cannot afford to be an ordinary bank. It will be required to devise new methods of financing, of raising funds, of developing export markets, of supporting exporters and financing small exporters in particular. It may be required to develop markets for Pakistani products in Africa or economies in transition. By evaluating the activities of other EXIM Bank and taking into account Pakistan's economic policies and Pakistan's export markets and products and targets, the EXIM Bank is the support need of a Trade Policy”. (Iqbal M. Khan 1998)

\section{Trade Policy}

Finally a new concept of trade policy should be approached the Total Trade Policy Management approach which will globalize the trade policy of Pakistan. As can be seen, the new strategy would have to be bilateralism in determining trade agreements. Under the current circumstances it will not be possible to pursue multilateralism for the reason that interests are divided owing to allegiance to certain groups.

\section{Private Sector Commercial Counselors}

The private sector industry associations should select their commercial counselors and post them in their markets to promote their products and bargain for bigger market share.

In fact the issue can be dealt only through a Total Trade Policy Management Regime.

The assistance from the Trade Academy should be forthcoming to give the guidelines to the policy based upon the research and facts available on a particular country. It is only possible to adopt a total trade policy if we work on each country to determine its needs and the economic policy it adheres to. Such work can only be carried out at the Trade Academy. The CTotal Trade Policy Management helps in adopting a policy to handle with extreme caution all-important trading partners. This should be regardless of 'blocs' and regions. It eventually leads to other regional partner's joining-in.

\section{REFERENCES}

Anila McGahan (1994)

Austin, J.E (1990)

Ariff M and Hall Hill (1985)
"Industry Structure and Competitive Advantage" HBR Nov-Dec 94

"Managing in Developing Countries" The Free Press, New York

"Export Oriented Industrialization-ASEAN Experience" Allen and Unwin 
Journal of Poverty, Investment and Development - An Open Access International Journal Vol.1 2013

Australia

Axtell, E.R (1989)

"The Do's and Taboos of International Trade. A Small Business Primer" John Wiley \& Sons. New York

Choate, Pat and Juyne Linger (1988)

"Tailored Trade: Dealing with the World as it is" Harvard Business Review (Jan-Feb. 1988)

, (1990)

Drucker Peter (1971)

Fairbanks, M and Stacy Lindsay (1997)

Haq Irfan U1, et al (1995)

Jean-Francos Richard

Khan, Iqbal M. (1994)

Khan, Iqbal M. (1994)

Khan, Iqbal M. (1997)

Ohmae, Kenichi (1990)

Ohmae, Kenichi (1995)

Porter, Michel (1990)

Porter, Michel (1990)

Sprout, Andry T, and Bruce R Scott. (1977)

Derg, Norman A., Constantinos Markides (1987)

Garelli, Stephan (1997)

Robert Hayes, Gory Pisana (1994)

Salter, W.E.G (1966)

Schumpeter, Joseph (1934)
"World Trade“ Economist Sept 221990

“The Battle for Brainpower" A Survey of Talent pps: 3-9 Economist. Oct. 7, 2006

“The Age of Discontinuity” Pan Books Ltd. London. $1^{\text {st }}$ Published 1968

"Plowing the Sea" Harvard Business School Press. Cambridge USA

"Trade Technology and International Competitiveness" World Bank, EDI Development Studies

“The New World Economy \& Global Governance” World Bank

"Export Marketing Education Vital for Trade Promotion “ Daily Newspaper 'Dawn'

“Trade Promotion Vital to Export-led Economy" Daily Newspaper 'The News' $8^{\text {th }}$ July

“Determining Pakistan's Competitiveness” Report for Ministry of Industries. Unpublished

“The Borderless World” Harper Business/Harper Collins Publication

"The End of the Nation State: The Rise of the Regional Economies" The Free Press New York

"The Competitive Advantage of Nations" The Free Press New York

"The Competitive Advantage of Nations" Harvard Business Review. MA USA reprint No 90211

“Japan D1. A Strategy for Economic Growth” HBS Publication

“Asia’s Four Little Dragon,” HBS Publication No. 9-386-186 (Revised March 1987)

"Four Fundamental Forces of Competitiveness"

“Beyond World-Class (New Mfg. Strategy)” HBR Jan-Feb 94

"Productivity and Technical Change" Cambridge UK, Cambridge University Press

"The Theory of Economic Development" Cambridge: Mass: Harvard University Press 
Journal of Poverty, Investment and Development - An Open Access International Journal Vol.1 2013

Page Sheila (1994)

Friendman Thomas (1999)

Ramamurti, Ravi 1988
"How Developing Countries Trade" Routledge, London

"The Lexus and the Olive Tree"

Taiwan "The Making of a Miracle", (Harvard Business School) Publication 9-388-053

Mathew, Jamie and Bruce R, Scott, (Supervisor) (1999) No. 9-700-039

Prewitt, Edward and Forest L. "SINGAPORE” Harvard Business School. Publication No. 9-793-096 Reinhardt (1993)

Kennedy, Robert E.,

"The Economic Gains from Trade: Theories of Strategic Trade" HBS Publication No. 9-796-184 